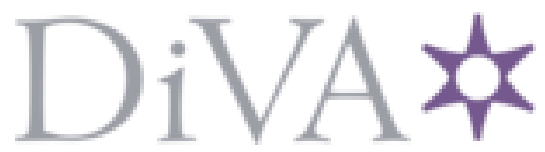

http://www.diva-portal.org

This is the published version of a paper presented at EuroCALL 2016.

Citation for the original published paper:

Allen, C., Berggren, J. (2016)

Digital literacy and sustainability: a field study in EFL teacher development.

In: Salomi Papadima-Sophocleous, Linda Bradley, Sylvie Thouësny (ed.), CALL communities and culture: short papers from EUROCALL 2016 (pp. 14-19).

https://doi.org/10.14705/rpnet.2016.eurocall2016.531

N.B. When citing this work, cite the original published paper.

Permanent link to this version:

http://urn.kb.se/resolve?urn=urn:nbn:se:Inu:diva-59163 


\title{
Digital literacy and sustainability - a field study in EFL teacher development
}

\section{Christopher Allen ${ }^{1}$ and Jan Berggren ${ }^{2}$}

\begin{abstract}
This project introduces the concept of digital literacy at a practical level to a group of EFL teachers within the context of a single work place; a technologically well-resourced upper secondary school in Sweden. English teachers were provided with a theoretical and practical overview of the digital literacy concept as described by Dudeney, Hockly, and Pegrum (2013) before being given the task of each teaching a lesson. The teachers' reflective experiences of incorporating digital literacy into advanced level English teaching were then evaluated through a focus group interview. The results obtained show the efficacy of incorporating small scale exploratory practice research projects alongside busy teaching schedules and administrative demands as well as developing teachers' perspectives on Information and Communications Technology (ICT) in the English as a Foreign Language (EFL) classroom. In addition, the project has promoted synergies and collaboration among a school staff engaged in the long-term goal of continued professional development.
\end{abstract}

Keywords: digital literacy, exploratory practice, in-service training.

\section{Introduction}

\subsection{In-service training and ICT}

In the era of digitalization, modern language teacher training faces significant challenges in responding to the pace of technological and educational change and incorporating these developments into a coherent blueprint for classroom practice. Digital literacy, as described by Dudeney et al. (2013), offers one possible

\footnotetext{
1. Department of Languages, Linnaeus University, Växjö, Sweden; christopher.allen@lnu.se
}

2. Department of Pedagogy, Linnaeus University, Växjö, Sweden; jan.berggren@Inu.se

How to cite this article: Allen, C., \& Berggren, J. (2016). Digital literacy and sustainability - a field study in EFL teacher development. In S. Papadima-Sophocleous, L. Bradley \& S. Thouësny (Eds), CALL communities and culture - short papers from EUROCALL 2016 (pp. 14-19). Research-publishing.net. https://oi.org/10.14705/rpnet.2016.eurocall2016.531 
framework to facilitate the integration of ICT and a language subject such as English. This publication provided EFL teachers with a comprehensive framework for the incorporation of Web 2.0 digital technology into their daily classroom routines.

This paper describes a small-scale project to introduce digital literacy to a group of EFL teachers. The teachers were first introduced to the digital literacy framework before being asked to select one or more digital learning activities which they should teach and then evaluate. The evaluation of their experiences was carried out in the form of a video recorded collegial focus group interview.

\subsection{Perspectives on teaching training}

Beginning in the 1980s, perspectives on professional teacher development have increasingly focused on teachers as reflective practitioners (Schön, 1983). Inspired by reflective practitioner perspectives, subsequent authors have suggested a formalization of the professional development process in the form of action research; small-scale research projects carried out by teachers in their classroom contexts in response to a perceived problem (Kemmis \& McTaggart, 1982). The action research tradition has, however, tended to be individualistic, with a focus on individual teachers focusing on problems in isolation. The work of Burns (2001) puts the spotlight instead on collaborative action research initiatives with the potential for staff to learn from one another in exploiting the potential synergies of collegial efforts.

More recently within language education, Exploratory Practice (EP) was put forward as a possible method for teachers investigating solutions to educational problems (Allwright, 1993; Allwright \& Bailey, 1991; Allwright \& Lenzuen, 1997). This alternative approach is a recognition of the significant demands made by reflective and action research projects on the working lives of busy teachers. A central tenet of the EP framework is bringing teachers together and promoting collegiality as an activity "best served if all involved are manifestly working for each other's development as well as their own" (Allwright, 2003, p. 129 quoted in Hanks, 2015, p. 614).

\subsection{Digital literacy}

In a series of recent publications (Hockly, 2012; Dudeney et al., 2013), digital literacy has been put forward as a means of seamlessly integrating technology into the foreign language classroom. 
Table 1. Digital literacy focus areas (adapted from Dudeney et al., 2013, p. 6)

\begin{tabular}{|l|l|l|l|}
\hline Language focus & Information focus & Connections & (re-)design \\
\hline print literacy & & & \\
\hline texting literacy & search literacy & & \\
\hline hypertext literacy & tagging literacy & personal literacy & \\
\hline multimedia literacy & information literacy & network literacy & \\
\hline gaming literacy & filtering literacy & participatory literacy & \\
\hline mobile literacy & & intercultural literacy & \\
\hline code literacy & & & remix literacy \\
\hline
\end{tabular}

The outline has been favourably received by the international EFL community. However, White (2015) has criticized the framework for a perceived imbalance in its focus on the receptive rather than productive skills.

\section{The study}

Eight English teachers with between two and 21 years' teaching experience at a large upper secondary school in southern Sweden took part in the study. The design of the project encompassed three practical stages:

- two initial seminars/workshops offering teachers a theoretical and practical overview of the concept of digital literacy as well as outlining the teaching task;

- teaching of a digital literacy-based lesson using one of the 50 activities provided in the Digital Literacies resource book;

- a concluding focus group interview in which the teachers offered their experiences of integrating digital literacy into advanced level English teaching.

Each teacher taught at least one lesson based on lesson plans provided by Dudeney et al. (2013). After teaching their lessons the teachers were gathered in a focus group interview where the teachers provided their reflective experiences of (1) incorporating digital literacy into advanced level English teaching at the school, (2) the extent to which digital resources can replace or augment 'traditional' course books and finally (3) the efficacy of lesson evaluation as a form of exploratory practice. The focus interview was recorded and transcribed for further analysis. 
Table 2. Outline of teacher activities and digital literacy areas in the focus group

\begin{tabular}{|c|c|c|c|}
\hline Teacher & $\begin{array}{l}\text { Activity from } \\
\text { resource book }\end{array}$ & Aim & $\begin{array}{l}\text { Digital } \\
\text { literacy }\end{array}$ \\
\hline EL & $\begin{array}{l}\text { No. 12: Sales } \\
\text { Techniques }\end{array}$ & $\begin{array}{l}\text { produce an advertisement } \\
\text { in the form of a vodcast }\end{array}$ & multimedia \\
\hline SJ & No. 27: Tree octopus & $\begin{array}{l}\text { raise awareness of the importance } \\
\text { of evaluating information on websites, } \\
\text { by visiting a number of spoof websites }\end{array}$ & information \\
\hline JK & No.3: Faking it & $\begin{array}{l}\text { raise awareness of social } \\
\text { networking profiles, online identity } \\
\text { and identity management }\end{array}$ & $\begin{array}{l}\text { personal, } \\
\text { network }\end{array}$ \\
\hline \multirow[t]{2}{*}{ MO } & $\begin{array}{l}\text { No.17: Choose your } \\
\text { own adventure }\end{array}$ & $\begin{array}{l}\text { raise awareness of and } \\
\text { implement basic game design }\end{array}$ & gaming \\
\hline & No. 18: History hunt & $\begin{array}{l}\text { create a local history quiz in the } \\
\text { form of a multimedia mobile app }\end{array}$ & $\begin{array}{l}\text { multimedia, } \\
\text { gaming }\end{array}$ \\
\hline \multirow[t]{2}{*}{ DS } & $\begin{array}{l}\text { No. 4: Extreme } \\
\text { Weather }\end{array}$ & $\begin{array}{l}\text { raise awareness of how to } \\
\text { convey a message via different } \\
\text { genres of online text }\end{array}$ & $\begin{array}{l}\text { print, } \\
\text { information }\end{array}$ \\
\hline & $\begin{array}{l}\text { No. 6: } \\
\text { Codeswitching }\end{array}$ & raise awareness of codeswitching & texting, print \\
\hline \multirow[t]{2}{*}{ AS } & $\begin{array}{l}\text { No. 12: Sales } \\
\text { Techniques }\end{array}$ & $\begin{array}{l}\text { produce an advertisement } \\
\text { in the form of a vodcast }\end{array}$ & multimedia \\
\hline & No. 44: Vox Pop & make a vodcast about culture & $\begin{array}{l}\text { intercultural, } \\
\text { multimedia }\end{array}$ \\
\hline \multirow[t]{2}{*}{ MSB } & $\begin{array}{l}\text { No. } 6 \text { : } \\
\text { Codeswitching }\end{array}$ & raise awareness of codeswitching & texting, print \\
\hline & $\begin{array}{l}\text { No. 12: Sales } \\
\text { Techniques }\end{array}$ & $\begin{array}{l}\text { produce an advertisement } \\
\text { in the form of a vodcast }\end{array}$ & multimedia \\
\hline
\end{tabular}

\section{Results and discussion}

The responses to the interview questions are presented below in accordance with the three focus areas outlined above.

\subsection{The teachers' reflective experiences of incorporating digital literacy into advanced level English teaching}

The teachers all agreed that the integration of digital literacy into advanced level English teaching greatly stimulated interest in learning English, especially among pupils who had opted for more practical, vocationally-orientated subject combination profiles. Teachers responsible for more academically-orientated subjects in the Technology Program were also positive, claiming that the incorporation of digital 
literacy into their EFL classrooms had inspired their pupils. Staff also reported that the opportunity to work with intercultural literacy was most appreciated by the pupils involved. Pupils were offered the opportunity to explore communication in a cultural content involving people coming from other cultures, through Skype or recording a video presenting their hometown.

\subsection{The extent to which digital resources can replace or augment 'traditional' coursebooks}

Teachers highlighted the added multimedia dimension to their teaching which introduced a new level of creativity into their classroom practice, having previously worked with more traditional language teaching activities such as gap-filling, vocabulary lists and coursebook exercises. A number of teachers expressed that their pupils performed better when digital literacies integrated into their English teaching, since it was easier to adapt their teaching to the needs of individual pupils. It was also noted that the approach lent itself readily to the incorporation of authentic material in their classrooms, encouraging pupils to think critically about the reliability of digital information sources.

Another positive feature was the opportunity to analyse texts from different digital contexts or genres, as well as adapting texts from one digital context to another, such as converting a blog entry into a tweet, Facebook post, etc. These comparisons led to a heightened awareness among pupils of the differences between informal and Standard English varieties. Other pupil discussions revolved around open educational resources and Creative Commons digital copyright issues.

\subsection{The efficacy of lesson evaluation as a form of exploratory practice (collegial learning)}

Participating in the Digital Literacy project, teachers had an opportunity to learn and reflect upon concepts of professional relevance of digital literacies. Many teachers found that they had developed their repertoire of teaching activities in which digital literacies are integrated in advanced English language learning. Above all, this group of teachers now has access to concepts of professional relevance and an overview of digital literacies, which can be made of use in future in-service training, or collegial learning. Developing a professional language and an ability to teach digital literacies constitutes an updated professional identity for this group of teachers and is also a guarantee in itself of sustainable in-service training. 


\section{Conclusion}

A major challenge for researchers is to bring positive change in the classroom without impinging too heavily on other professional priorities such as lesson planning, grading and assessment and pastoral considerations. The results suggest a way forward in promoting the sustainable incorporation of ICT into mainstream English language teaching and encouraging professional development on a collegial level. Future research will be directed towards building upon this collegial knowledge of digital literacy in developing greater consistency and objectivity in the assessment of digital projects.

\section{Acknowledgements}

The authors would like to thank the Department of Languages, Linnaeus University and Kalmarsundsgymnasieförbund, Kalmar Muncipality, Sweden for financial support in attending the EUROCALL 2016 conference.

\section{References}

Allwright, D. (1993). Integrating 'research' and 'pedagogy': appropriate criteria and practical possibilities. In J. Edge \& K. Richards (Eds), Teachers develop teachers research (pp. 125135). Oxford: Heinemann.

Allwright, D. (2003). Exploratory practice: rethinking practitioner research in language teaching Language Teaching Research, 7(2), 113-141.

Allwright, R., \& Bailey, K. (1991). Focus on the language classroom: an introduction to classroom research for language teachers. Cambridge University Press.

Allwright, D., \& Lenzuen, R.(1997). Exploratory practice: work at the Cultura Inglesa, Rio de Janeiro, Brazil. Language Teaching Research, 1, 73-79. https://doi.org/10.1177/136216889700100105

Burns, A. (2001). Collaborative action research for English language teachers. Cambridge University Press.

Dudeney, G., Hockly, N., \& Pegrum, M. (2013). Digital literacies. Pearson Education

Hanks, J. (2015). Language teachers making sense of exploratory practice. Language Teaching Research, 19(5), 612-633.

Hockly, N. (2012). Digital literacies. ELT J, 66(1), 108-112. https://doi.org/10.1093/elt/ccr077

Kemmis, S., \& McTaggart, R. (1982). The action research planner (rev. ed). Geelong: Deakin University Press.

Schön, D. (1983). The reflective practitioner: how professionals think in action. NY: Basic Books. White, G. (2015). Digital literacies. ELT J, 69(3), 345-347. 


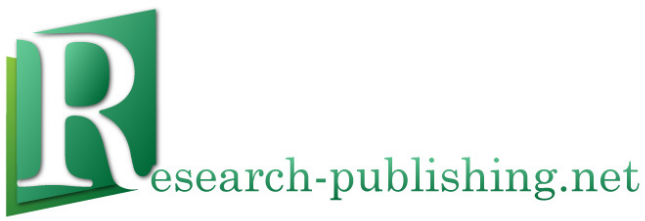

Published by Research-publishing.net, not-for-profit association Dublin, Ireland; Voillans, France, info@research-publishing.net

(C) 2016 by Editors (collective work)

(C) 2016 by Authors (individual work)

\section{CALL communities and culture - short papers from EUROCALL 2016 Edited by Salomi Papadima-Sophocleous, Linda Bradley, and Sylvie Thouësny}

Rights: All articles in this collection are published under the Attribution-NonCommercial -NoDerivatives 4.0 International (CC BY-NC-ND 4.0) licence. Under this licence, the contents are freely available online as PDF files (https://doi. org/10.14705/rpnet.2016.EUROCALL2016.9781908416445) for anybody to read, download, copy, and redistribute provided that the author(s), editorial team, and publisher are properly cited. Commercial use and derivative works are, however, not permitted.

\section{(9) $\Theta \Theta$}

Disclaimer: Research-publishing.net does not take any responsibility for the content of the pages written by the authors of this book. The authors have recognised that the work described was not published before, or that it is not under consideration for publication elsewhere. While the information in this book are believed to be true and accurate on the date of its going to press, neither the editorial team, nor the publisher can accept any legal responsibility for any errors or omissions that may be made. The publisher makes no warranty, expressed or implied, with respect to the material contained herein. While Research-publishing.net is committed to publishing works of integrity, the words are the authors' alone.

Trademark notice: product or corporate names may be trademarks or registered trademarks, and are used only for identification and explanation without intent to infringe.

Copyrighted material: every effort has been made by the editorial team to trace copyright holders and to obtain their permission for the use of copyrighted material in this book. In the event of errors or omissions, please notify the publisher of any corrections that will need to be incorporated in future editions of this book.

Typeset by Research-publishing.net

Cover design by (C) Easy Conferences, info@easyconferences.eu,www.easyconferences.eu

Cover layout by (c) Raphaël Savina (raphael@savina.net)

Photo "bridge" on cover by (C) Andriy Markov/Shutterstock

Photo "frog" on cover by (C) Fany Savina (fany.savina@gmail.com)

Fonts used are licensed under a SIL Open Font License

ISBN13: 978-1-908416-43-8 (Paperback - Print on demand, black and white)

Print on demand technology is a high-quality, innovative and ecological printing method; with which the book is never 'out of stock' or 'out of print'.

ISBN13: 978-1-908416-44-5 (Ebook, PDF, colour)

ISBN13: 978-1-908416-45-2 (Ebook, EPUB, colour)

Legal deposit, Ireland: The National Library of Ireland, The Library of Trinity College, The Library of the University of Limerick, The Library of Dublin City University, The Library of NUI Cork, The Library of NUI Maynooth, The Library of University College Dublin, The Library of NUI Galway.

Legal deposit, United Kingdom: The British Library.

British Library Cataloguing-in-Publication Data.

A cataloguing record for this book is available from the British Library.

Legal deposit, France: Bibliothèque Nationale de France - Dépôt légal: décembre 2016. 